\title{
DETECTION IN NORMAL URINE OF PROTEIN RESEMBLING BENCE JONES PROTEIN
}

\author{
By G. T. STEVENSON * \\ (From the Department of Medicine, The University of Sydney, Sydney, Australia)
}

(Submitted for publication December 14, 1959; accepted March 4, 1960)

Bence Jones (1), in 1848, described an unusual protein present in high concentration in the urine of a patient suffering from multiple myeloma. Similar urinary proteins have subsequently been found in many cases of this disease, and are designated by the collective term "Bence Jones protein." They are characterized by their behavior when heated in solution, usually giving two identifying reactions if present in sufficient concentration $(2,3): a)$ with the $\mathrm{pH}$ near 5 , precipitation occurs between $45^{\circ}$ and $60^{\circ} \mathrm{C} ; b$ ) subsequent heating to boiling causes complete or partial solution of the precipitate, which re-forms on cooling.

Studies of other physicochemical properties have given rather diverse results. Molecular weights in the range 24,000 to 90,000 have been calculated (4), with a median about 44,000 (3). Total and $\mathrm{N}$-terminal amino acid analyses have given varying results $(3,5)$. Despite this heterogeneity of the group as a whole, specimens from any one individual have usually tended to physical and chemical homogeneity (5).

Recent studies of antigenic structure $(6,7)$ suggest that all Bence Jones proteins are antigenically related to the serum gamma globulins. In addition, any individual Bence Jones protein lacks some gamma globulin determinants, but possesses determinants unique for a group of Bence Jones proteins $(7)$ and possibly for itself alone (8).

There is lack of agreement on conditions of occurrence of this protein in urine. A positive heat test has been said to be almost pathognomonic of multiple myeloma and to be present in about 50 per cent of cases of this disease (9); however, sporadic reports occur $(10,11)$ of detection of the protein by this method in other diseases. Immunochemical testing is reported to detect it in practically all cases of myeloma (12), and in some cases of other diseases (13).

\footnotetext{
* Reginald Maney Lake and Amy Laura Bonamy Research Fellow.
}

This paper describes attempts to detect Bence Jones protein by immunochemical means in normal serum and urine. An antiserum to gamma globulins ${ }^{1}$ was used. Any protein detected by its reaction with this antiserum must be further characterized in order to distinguish gamma globulins, Bence Jones protein, and any other gamma-related protein. Criteria for such characterization were: heat stability at $55^{\circ} \mathrm{C}$, solubility of heated products at $98^{\circ} \mathrm{C}$, and diffusion coefficient.

The main investigation consists of studies of solutions of serum and urine protein, and of filtrates obtained from these at $55^{\circ}$ and $98^{\circ} \mathrm{C}$. Two preliminary experiments on gamma globulins and Bence Jones proteins were thought necessary to assess rates of denaturation at $55^{\circ} \mathrm{C}$, solubility of denatured products at $98^{\circ} \mathrm{C}$, and antigenic activity $^{2}$ of protein remaining in solution after heating at these temperatures.

\section{MATERIALS AND METHODS}

The protein solvent used extensively in this work consisted of $0.15 \mathrm{M} \mathrm{NaCl}-0.2 \mathrm{M}, \mathrm{pH} 5$, sodium acetate buffer, $4: 1 \mathrm{vol} / \mathrm{vol}$; this is subsequently referred to as

1 The antiserum was prepared to Cohn Fraction II, which contains about 80 per cent of the plasma gamma globulins. These globulins also occur in Fraction III-1 (14), which was therefore included in physicochemical studies. The gamma globulins have a predominant component of sedimentation rate $7 \mathrm{~S}$ and a minor component of 19S; these show some antigenic differences (15).

Protein antigenically related to the gamma globulins, i.e., reacting with antibodies prepared to them, is designated "gamma-related." Gamma-related proteins are known to include $7 \mathrm{~S}$ and 19S gamma globulins, myeloma serum globulins, pathological macroglobulins and Bence Jones proteins (3).

An antiserum to gamma globulins can be expected to react with all Bence Jones protein (7), although some of these may be antigenically distinct from each other $(7,8)$, i.e., an antiserum to any single such pathological protein need not react with all others.

2 The term "antigenic activity" is used to refer to the degree of interaction of considered proteins with a given antiserum, interaction being estimated by precipitin, precipitin-inhibition or other method. 
"saline-acetate." "Sixty per cent saturated" ammonium sulfate implies $43 \mathrm{~g}$ of the salt per $100 \mathrm{ml}$ of solvent, representing 60 per cent saturation at $2^{\circ} \mathrm{C}$.

Serum gamma globulin fractions were obtained from Commonwealth Serum Laboratories, Melbourne, Australia. Bence Jones proteins (BJ1 to BJ6) were obtained from urines of 6 patients (selected from 18) suffering from multiple myeloma. The proteins were isolated by repeated precipitation with 60 per cent saturated ammonium sulfate.

Normal urine and serum were obtained from 7 healthy adults, $A$ to $E$, males, and $F$ and $G$, females. Urine was collected over a 24 hour period. After each voiding merthiolate was added to 0.01 per cent and the urine was immediately refrigerated. On completion of collection any deposits were removed by filtration, and concentration by ultrafiltration was begun immediately. When the residual volume had reached about $50 \mathrm{ml}$ it was dialyzed against saline-acetate. Solid ammonium sulfate was added to 60 per cent saturation and the mixture equilibrated overnight at $2^{\circ} \mathrm{C}$. The precipitate was packed by centrifugation and, if not used immediately, stored under moist conditions at $2^{\circ} \mathrm{C}$. Two precipitates from Subject A contained 8.2 and $9.0 \mathrm{mg}$ of nondialyzable nitrogen. Serum was obtained during the urine collection period. One $\mathrm{ml}$ was diluted to $10 \mathrm{ml}$ with saline-acetate and the protein was precipitated and stored as detailed for the urine concentrates.

For use in Experiment 3 precipitates were dispersed in saline-acetate: those from urine in $1 \mathrm{ml}$, those from serum in $5 \mathrm{ml}$ (but sometimes in different volumes, as indicated in the tabulated results). Any substance not dissolved after 2 hours at $37^{\circ} \mathrm{C}$ was removed by centrifugation. Serum precipitates dissolved readily with negligible insoluble residue. Urine precipitates dissolved incompletely, with a dark brown to black residuum usually containing less than $0.5 \mathrm{mg}$ of nondialyzable nitrogen; the solutions were of deep brown color with a strong uriniferous odor. Proteins finally obtained in solution are subsequently referred to as "globulins."

Ultrafiltration was performed by a modification of the method described by Grant (16). The sample was filtered through 4 feet of 24/32 inch Visking dialysis casing held linearly inside a 3 inch diameter Perspex tube, a vacuum of $720 \mathrm{~mm} \mathrm{Hg}$ being maintained outside the casing. Stretching of the casing was prevented by enclosing it in a steel mesh tube of the same diameter. Concentration of $1 \mathrm{~L}$ of urine to $50 \mathrm{ml}$ required about 30 hours. Of $100 \mathrm{mg}$ of Bence Jones protein dissolved in $1 \mathrm{~L}$ of buffered saline, over 95 per cent remained after concentration to $45 \mathrm{ml}$.

Protein quantitation was usually by a biuret method. This was inapplicable to small amounts of protein recovered from large urine volumes because of the absorbance of considerable associated pigment; in these cases nondialyzable $\mathrm{N}$ was determined by the Kjeldahl method. The biuret method was modified from that described by Goa (17). Protein was precipitated by trichloroacetic acid and separated by centrifugation at at least $10,000 \mathrm{G}$ for 15 minutes. To the precipitate was added a 4 per cent solution of Goa's Benedict reagent in 3 per cent $\mathrm{NaOH}$. The absorbance at $350 \mathrm{~m} \mu$ was read after 15 to 60 minutes. The amount of protein was then determined from a curve constructed from gravimetric fraction II-1, 2 standards. For estimation of insoluble protein the biuret reagent was added directly to washed precipitate, which always dissolved readily.

Antisera to Fraction II were prepared in rabbits by single 4 week courses of intravenous alum-precipitated protein as recommended by Kabat and Mayer (18). Sera were decomplemented with bovine serum albumin (BSA)-antiBSA specific precipitate and stored at $-30^{\circ}$ C. Results presented in this paper were obtained by using a single pool of 6 sera. By the immunoelectrophoretic technic (19) this pool contained antibodies only to the gamma antigenic group among the serum proteins.

Precipitin tests in agar gel, using the double diffusion plate method, were performed essentially as described by Ouchterlony (20). Reservoirs were filled only once. Quantitative precipitin tests were porformed as detailed by Kabat and Mayer (18), except that precipitates were estimated by a biuret instead of a Kjeldahl method. Analyses of supernatants for free antigen or antibody were carried out by precipitin tests on Ouchterlony plates.

The precipitin-inhibition test consisted of incubating an excess of antiserum with the sample of unknown antigenic activity and subsequently titrating residual antibody; titration involved assessing how much Fraction II had to be added to a given volume of antiserum in order just to produce antigen excess. One $\mathrm{ml}$ of the unknown preparation (made up to final volume with phosphatebuffered saline to bring the $\mathrm{pH}$ to $7.0 \pm 0.2$ ) was incubated with $1 \mathrm{ml}$ of antiserum at $37^{\circ} \mathrm{C}$ for 1 hour, then at $2^{\circ} \mathrm{C}$ for 24 hours. Precipitate was spun off and $0.2 \mathrm{ml}$ lots of the supernatant were added to a series of tubes containing amounts of Fraction II in geometric progression with common ratio 1.2. The tubes were incubated and antigen excess then sought by precipitin tests on Ouchterlony plates.

Heating and filtering were standardized as follows. Solutions in narrow tubes were placed in a water bath kept at the indicated temperature; timing was begun from this moment. The tubes were stoppered after an interval allowing the contents to approach ambient temperature and were intermittently agitated. All filtrations were through Whatman no. 542 paper in an oven held within the indicated temperature range; funnels were covered to minimize evaporation. Filtering of urine globulins at $98^{\circ} \mathrm{C}$ had to be assisted by slight suction; the same degree of suction was applied for the serum globulins.

\section{RESULTS}

Bence Jones proteins and gamma globulins; heat stability and solubility of heated products. These results describe essentially endpoints attained in the overall reaction (dissolved protein $\rightleftharpoons$ 
TABLE I

Protein solutions heated at $55 \pm 1^{\circ} C$ for 15 minutes then filtered at $55 \pm 2^{\circ} \mathrm{C}$ for 15 minutes

\begin{tabular}{lccl}
\hline & \multicolumn{3}{c}{ Protein } \\
\hline Original & $\mu g / m l$ & $\mu g / m l$ & $\mu g / m l$ \\
$\quad$ concentrations & 5,000 & 1,000 & 200 \\
Concentrations & & & \\
$\quad$ in filtrates of : & & & \\
BJ1 & 2,000 & 530 & 190 \\
BJ2 & 3,500 & 850 & $230^{*}$ \\
BJ3 & 1,600 & 510 & \\
BJ4 & 1,200 & 380 & \\
BJ5 & 1,800 & 600 & 210 \\
BJ6 & 1,700 & 710 & \\
Fraction II-1,2 & $5,100^{*}$ & & \\
Fraction II-3 & $5,200^{*}$ & & \\
Fraction III-1 & & $1,050 \dagger$ & \\
\hline
\end{tabular}

* Turbidity not noted prior to filtering.

$\dagger$ Slight turbidity after 15 minutes, persisting in filtrates obtained at $55^{\circ} \mathrm{C}$ or at room temperature.

precipitated protein) on heating various preparations at $55^{\circ}$ or $98^{\circ} \mathrm{C}$. The solvent used throughout was the $\mathrm{pH} 5$ saline-acetate. With heating and filtering standardized as previously described, results varied by up to 20 per cent when duplicate experiments were run at different times. The averaged results presented should therefore be taken to indicate an order of magnitude only.

TABLE II

Protein solutions heated in a boiling water bath for 5 minutes then filtered at $98 \pm 4^{\circ} \mathrm{C}$ for 5 minutes

\begin{tabular}{|c|c|c|c|}
\hline \multirow{2}{*}{ 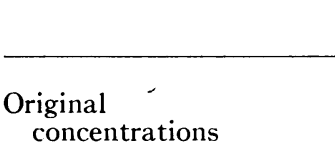 } & \multicolumn{3}{|c|}{ Protein } \\
\hline & $\begin{array}{l}\mu g / m l \\
5,000\end{array}$ & $\begin{array}{l}\mu g / m l \\
1,000\end{array}$ & $\begin{array}{c}\mu g / m l \\
200\end{array}$ \\
\hline $\begin{array}{l}\text { Concentrations in } \\
\text { filtrates of : }\end{array}$ & & & \\
\hline $\begin{array}{l}\text { BJ1 } \\
\text { BJ2 } \\
\text { BJ3 } \\
\text { BJ4 } \\
\text { BJ5 } \\
\text { BJ6 }\end{array}$ & $\begin{array}{r}1,800 \\
1,200 \\
900 \\
680 \\
1,050 \\
1,400\end{array}$ & $\begin{array}{c}1,300^{*} \\
1,200 \\
850 \\
490 \\
1,100^{*} \\
1,300^{*}\end{array}$ & $\begin{array}{l}230^{*} \\
230^{*} \\
240^{*}\end{array}$ \\
\hline Fraction $\mathrm{II}-1,2$ & 18 & $<10$ & \\
\hline Fraction II-3 & 28 & $<10$ & \\
\hline Fraction III-1 & & 32 & $<10$ \\
\hline Fraction II + BJ2, $\begin{array}{r}4: 1 \\
24: 1\end{array}$ & $\begin{array}{r}280 \dagger \\
50 \ddagger\end{array}$ & & \\
\hline Fraction II + BJ4, $\begin{array}{r}4: 1 \\
24: 1\end{array}$ & $\begin{array}{r}205 \dagger \\
55 \ddagger\end{array}$ & & \\
\hline
\end{tabular}

* Solution clear prior to filtering.

$\dagger+\ddagger$ Compare recoveries from solutions containing only $\mathrm{BJ} 2$ or $\mathrm{BJ} 4$ at corresponding concentrations $(1,000 \mu \mathrm{g}$ per $\mathrm{ml}$ and $200 \mu \mathrm{g}$ per $\mathrm{ml}$ ).
Table I sets forth the results of heating and filtering at $55^{\circ} \mathrm{C}$ for durations used in Experiment 3. Effects of varying the duration of heating were studied by removing solutions from the water bath at intervals, chilling, and centrifuging in the cold. Precipitation of most Bence Jones proteins reached a plateau at about 40 minutes, the extent of precipitation being similar to that shown in Table $\mathrm{I}$; maximal precipitation of $\mathrm{BJ} 2$ required 160 minutes.

Table II shows the results of heating and filtering at $98^{\circ} \mathrm{C}$, again for durations used in Experiment 3. Material used for the experiment depicted in Table III was obtained by heating the indicated protein at $70^{\circ} \mathrm{C}$ and washing the resulting precipitate with saline-acetate at room temperature; in no case was much precipitate lost in washing. The precipitates were suspended in sa-

TABLE III

Suspensions of washed precipitates of denatured proteins heated in a boiling water bath for 5 minutes then filtered at $98 \pm 4^{\circ} C$ for 5 minutes

\begin{tabular}{|c|c|c|}
\hline Precipitate of & $\begin{array}{c}\text { Total } \\
\text { protein } \\
\text { in filtrate }\end{array}$ & $\begin{array}{l}\text { Protein } \\
\text { remain- } \\
\text { ing in } \\
\text { solution } \\
\text { at room } \\
\text { temperature }\end{array}$ \\
\hline $\begin{array}{l}\text { BJ1 } \\
\text { BJ } 2 \\
\text { BJ6 } \\
\text { Fraction II-1,2 }\end{array}$ & $\begin{array}{r}\mu \mathrm{g} / \mathrm{ml} \\
1,000 \\
1,200 \\
1,050 \\
<10\end{array}$ & $\begin{array}{c}\mu g / m l \\
820 \\
780 \\
900\end{array}$ \\
\hline
\end{tabular}

line-acetate, then heated and filtered at $98^{\circ} \mathrm{C}$. All Bence Jones filtrates became turbid at room temperature; protein concentrations were therefore determined in the total mixtures and in second filtrates obtained at room temperature. The latter filtrates again became turbid on heating at $55^{\circ} \mathrm{C}$.

Bence Jones proteins, gamma globulins and heated products; immunochemical studies. Precipitin reactions in agar plates are depicted in Figures 1 and 2. In Figure 2 one can compare the precipitate bands formed by a native Bence Jones protein (BJ6) and by a solution (BJ6dn) obtained on dissolving, at $98^{\circ} \mathrm{C}$, a washed heat precipitate of the same protein. Note the absence of "spur" formation on the coalescence, the similar curvatures and the similar locations along the antiserum-antigen radii. Such a lack of distinction 
between native and heated preparations was also obtained $a$ ) using the five other Bence Jones proteins; $b$ ) using antisera prepared to a Bence Jones protein $(\mathrm{BJ} 1)$ or to a heat precipitate of this protein.

Figures 3 and 4 depict quantitative precipitin reactions of the antiserum with its homologous antigen (Fraction II), a Bence Jones protein (BJ6) and several heated preparations of BJ6.

With all six Bence Jones proteins, precipitininhibition tests failed to show any difference in antigenic activity between native protein and protein remaining in solution after filtering at $98^{\circ} \mathrm{C}$. The small amounts of protein in $98^{\circ} \mathrm{C}$ filtrates of

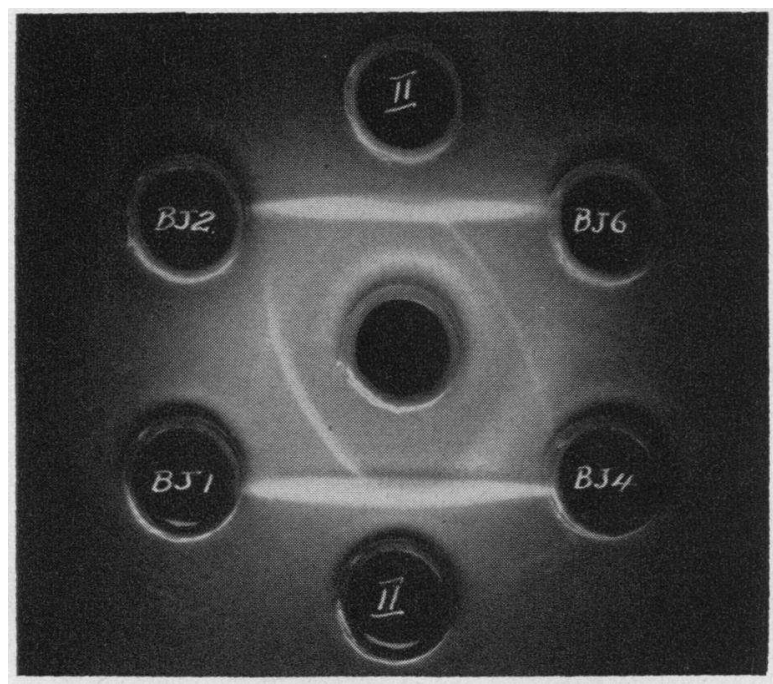

Fig. 1. Agar precipitation patterns of ANTI-II SErum (Central Well) with Fraction II and Bence JONES PROTEINS.

Fractions II and III-1 gave the same precipitininhibition as did the native proteins at these low concentrations.

Serum and urine globulins; immunochemical studies. Samples from A were examined on five occasions, from other subjects once. Solutions were fractionated for study of $a$ ) unheated solutions, filtered at room temperature; $b$ ) filtrates obtained by heating at $55 \pm 1^{\circ} \mathrm{C}$ for 15 minutes, then filtered at $55 \pm 2^{\circ} \mathrm{C}$ for 15 minutes; $c$ ) filtrates obtained by heating in a boiling water bath for 5 minutes, then filtered at $98 \pm 4^{\circ} \mathrm{C}$ for 5 minutes.

Turbidity on heating at $55^{\circ} \mathrm{C}$ occurred as indicated in Table IV; the deep brown color of urine

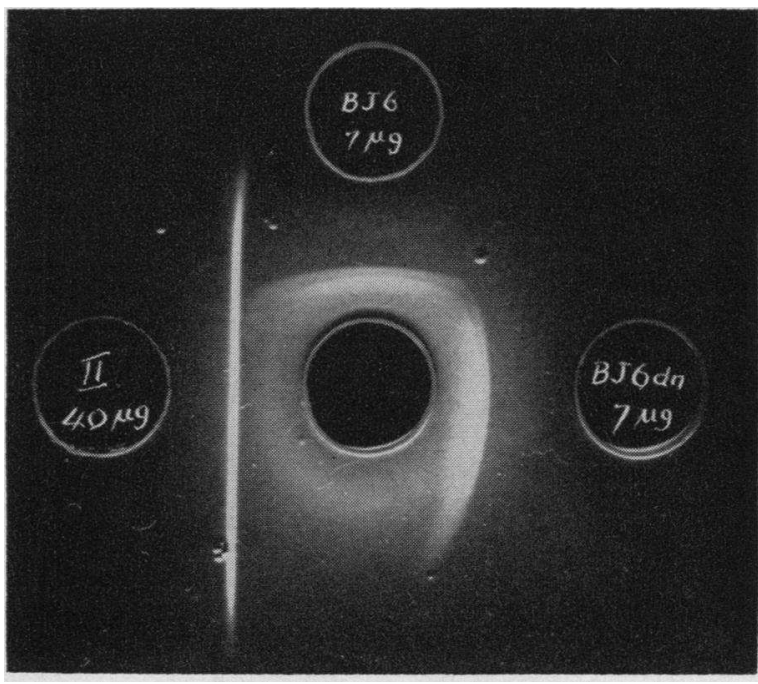

Fig. 2. Agar PRecipitation patterns of ANTI-II SErum with Fraction iI, a Bence Jones Protein (BJ6), AND A SOlution PREPAREd From heat-denatured BENCE JoNES PROTEIN (BJ6DN). Approximate amounts of antigen placed in each well are shown.

solutions prevented detection of slight turbidity. On heating in a boiling water bath flocculent precipitate appeared, in greater density in the serum solutions; filtrates from both solutions were clear and did not become turbid on cooling.

Agar precipitin patterns are shown in Figures 5 and 6 . Unheated serum globulin solutions gave the heaviest precipitate in a narrow, straight zone. In addition, a second band, farther from the antiserum reservoir and convex to it, was usually discernible. This pattern remained unchanged after heating and filtering at $55^{\circ} \mathrm{C}$. Filtrates obtained at $98^{\circ} \mathrm{C}$ never gave a visible precipitate.

Unheated urine globulins also gave a straight zone of precipitate. A second zone always occurred nearer the antiserum reservoir and concave to it; this consisted either of one broad band or of two parallel bands with little separation. Heating and filtering at $55^{\circ} \mathrm{C}$ regularly changed this pattern: the curved zones of precipitate became less dense and of less obvious curvature, and moved closer to or merged with the straight zone. With filtrates obtained at $98^{\circ} \mathrm{C}$ only the curved zone of precipitate appeared. This was always present, was similar to but fainter than the curved zone formed by unheated solutions, and gave with this zone a "reaction of identity" (20).

Precipitin-inhibition tests provided semiquan- 


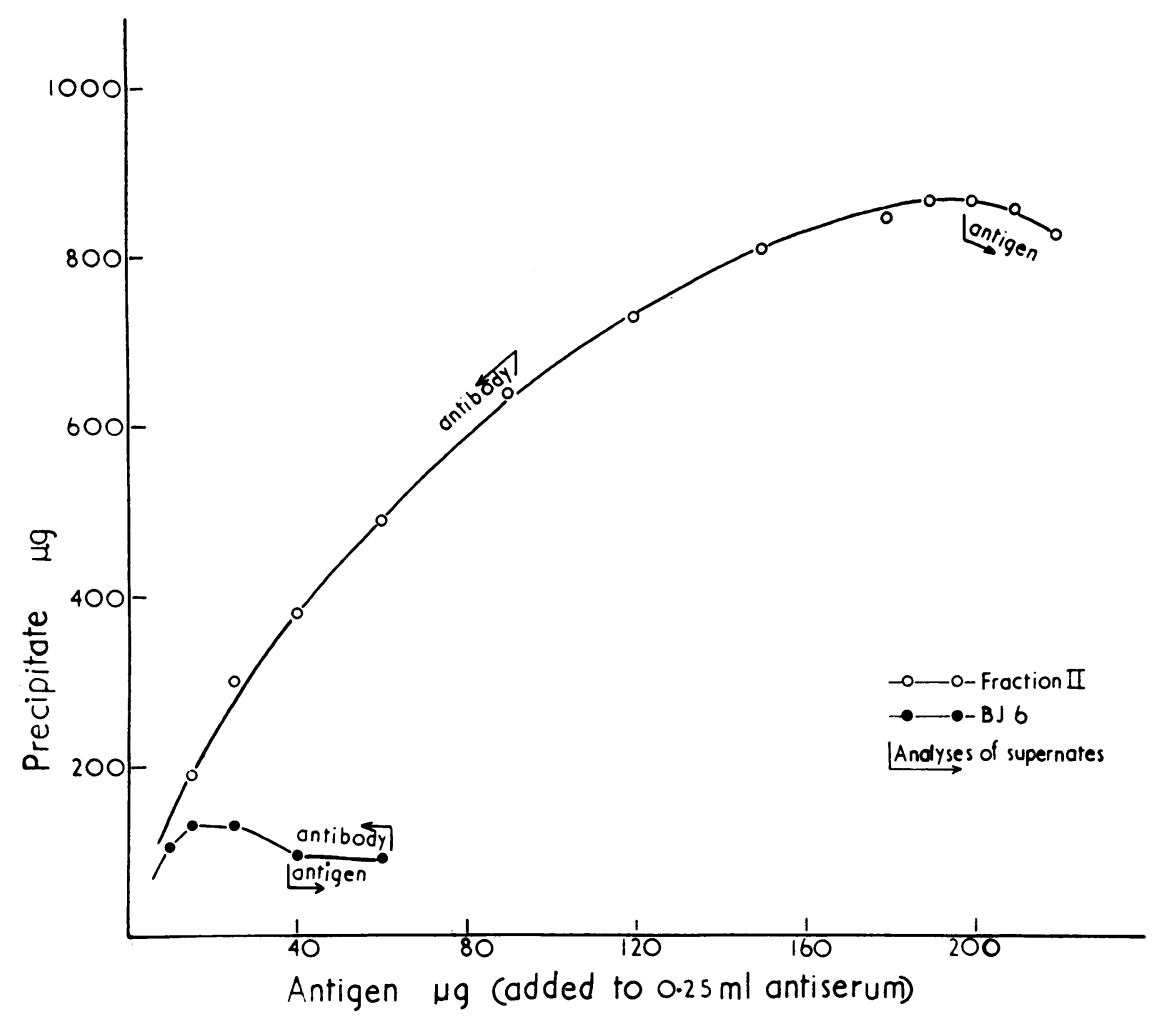

Fig. 3. Quantitative precipitin Reactions of anti-il serum with Fraction in ANd A Bence Jones protein.

titative confirmation of the above findings. Results using unheated solutions and $55^{\circ} \mathrm{C}$ filtrates are presented in Table IV. For each sample, the extents of precipitin-inhibition by equal volumes of unheated and heated solutions are compared. Serum globulins usually and urine globulins invariably showed decreased antigenic activity after heating. In the serum-urine pairs tabulated, urine components showed the greater decrease with significant frequency $[p=0.03(21)]$. Serum globulin filtrates obtained at $98^{\circ} \mathrm{C}$ never caused detectable precipitin-inhibition. Corresponding urine globulin filtrates (three from A, one from each other subject) gave detectable inhibition in all cases except that from $F$.

Some miscellaneous studies tested the possibility that observed differences between urine and serum gamma-related proteins could be due to dilution of gamma globulins or to urinary proteolytic action. Some sera (A1, A2, C) used in the above experiments were initially diluted 2,000 -fold with buffered saline and then treated as detailed for urines. No differences were detected between these preparations and those in which this large dilution was omitted. Addition of $2 \mathrm{ml}$ of serum or of $50 \mathrm{mg}$ of Fraction II to 24-hour urine volumes, followed by incubation for six hours at $37^{\circ} \mathrm{C}$, did not increase the amount of gammarelated protein subsequently found in $98^{\circ} \mathrm{C}$ filtrates of globulin concentrates. In each case there was a decrease, suggesting increased absorption by the greater amount of precipitate forming at $98^{\circ} \mathrm{C}$.

Recoveries of urinary gamma-related protein soluble at $98^{\circ} \mathrm{C}$ were attempted after adding varying amounts of urine globulin solution to a serum globulin solution (globulins from $1 \mathrm{ml}$ of serum in $2.5 \mathrm{ml}$ of saline-acetate). At least a 12 hour output of urine globulin had to be added for subsequent $98^{\circ} \mathrm{C}$ filtrates to give a detectable precipitate with the antiserum in agar.

\section{DISCUSSION}

Filterings at $55^{\circ}$ and $98^{\circ} \mathrm{C}$ were employed for their differential effects on concentrations of Bence Jones proteins and gamma globulins in 
mixed solutions. Results of Experiment 1 give some indications of the likely utility of these procedures. Of further interest is the behavior of precipitates formed by heating Bence Jones proteins and washing at room temperature with a solvent in which the native proteins readily dissolve. These precipitates dissolve to a large extent at $98^{\circ} \mathrm{C}$ and, on cooling, leave in solution some protein which reprecipitates on heating at $55^{\circ} \mathrm{C}$. This is consistent with the view that some

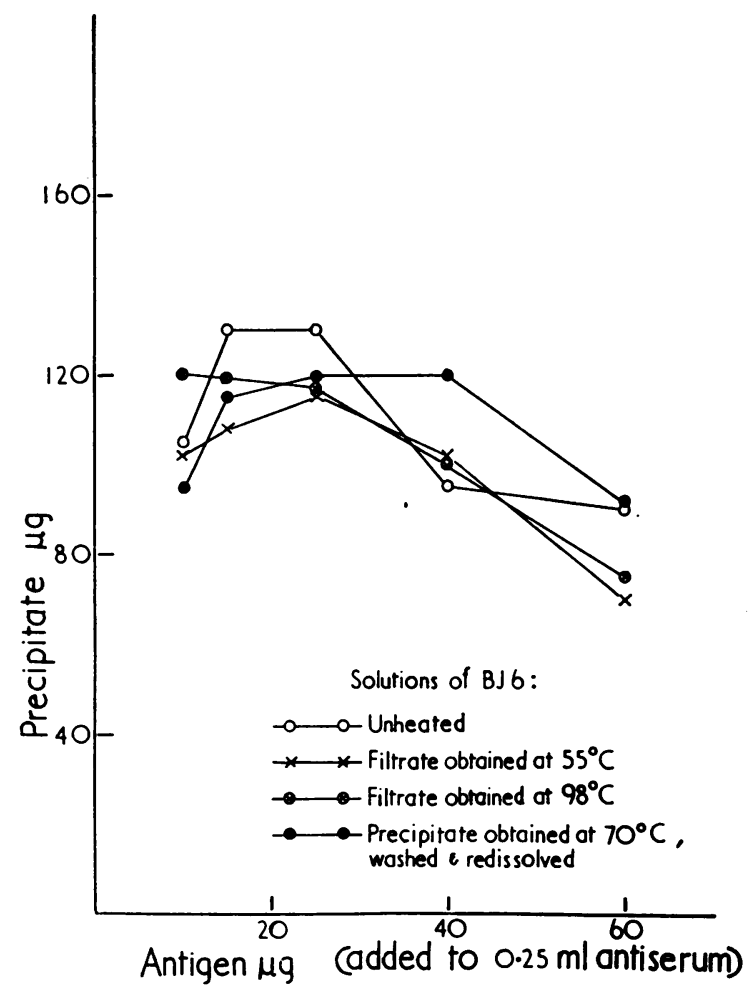

Fig. 4. QUantitative PRECIPITIN REACtions of ANTIII SERUM WITH VARIOUS PREPARATIONS OF A BENCE JONES PROTEIN.

dissolved denatured protein reverts to the native form on cooling from $98^{\circ} \mathrm{C}$.

Bence Jones proteins heated at temperatures up to $98^{\circ} \mathrm{C}$, if again obtained in solution at room temperature, were always antigenically indistinguishable from the native proteins. This is at variance with most immunological studies on denatured proteins [summarized by Boyd (22)] and implies either that change in antigenic structure on heat denaturation is minimal, or that any change is largely reversible. Ouchterlony plate appearances further suggest similar diffusion co-

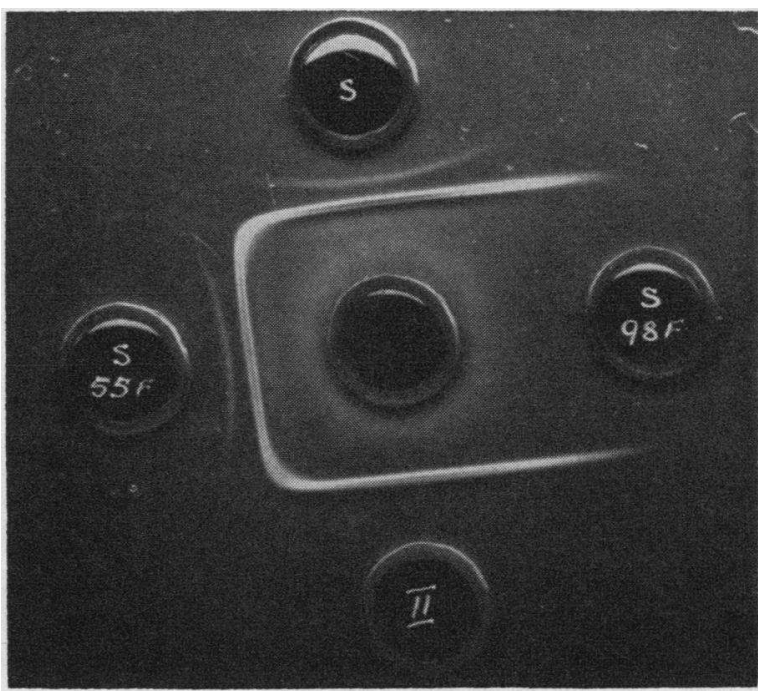

Fig. 5. Agar precipitation patterns of anti-II SERUM WITH Fraction II AND PREPARATIONS OF SERUM PROTEIN FROM SUBJECT B. $\mathrm{S}$ is unheated solution, S55F is the filtrate obtained at $55^{\circ} \mathrm{C}$, and $\mathrm{S} 98 \mathrm{~F}$ is the filtrate obtained at $98^{\circ} \mathrm{C}$.

efficients of native and heated products. The high solubilities of Bence Jones proteins at $98^{\circ} \mathrm{C}$, together with persistence of original antigenic structure in the protein subsequently remaining in solution at room temperature, were the basis of the scheme originally devised for detection of a small amount of these proteins in the simultaneous

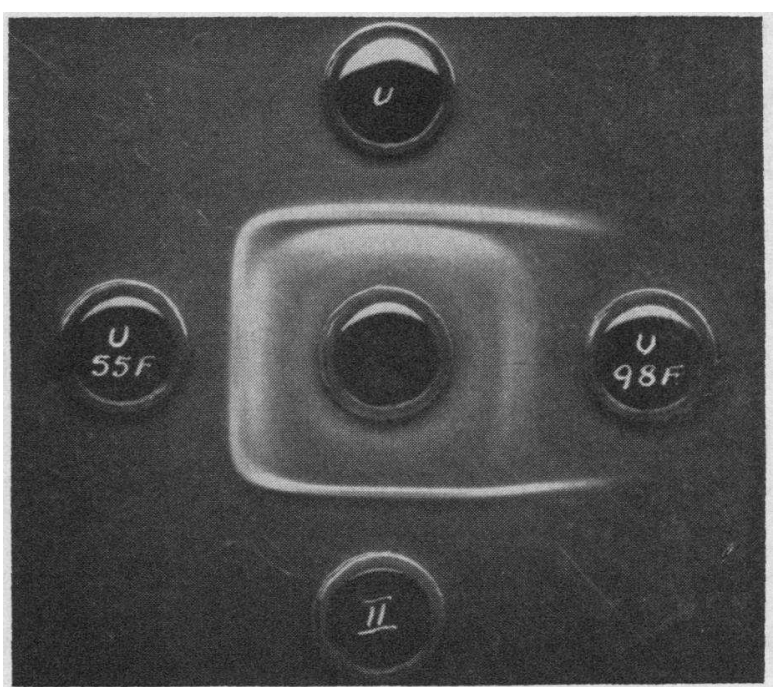

Fig. 6. Agar PRecipitation Patterns of ANTI-II SERUM WITH Fraction II AND PREPARATIONS OF URINE PROTEIN FROM SUBJECT B. $U$ is unheated solution, U55F is the filtrate obtained at $55^{\circ} \mathrm{C}$, and $\mathrm{U} 98 \mathrm{~F}$ is the filtrate obtained at $98^{\circ} \mathrm{C}$. 
TABLE IV

Serum and urine globulins; unheated solutions and filtrates obtained at $55^{\circ} \mathrm{C}$

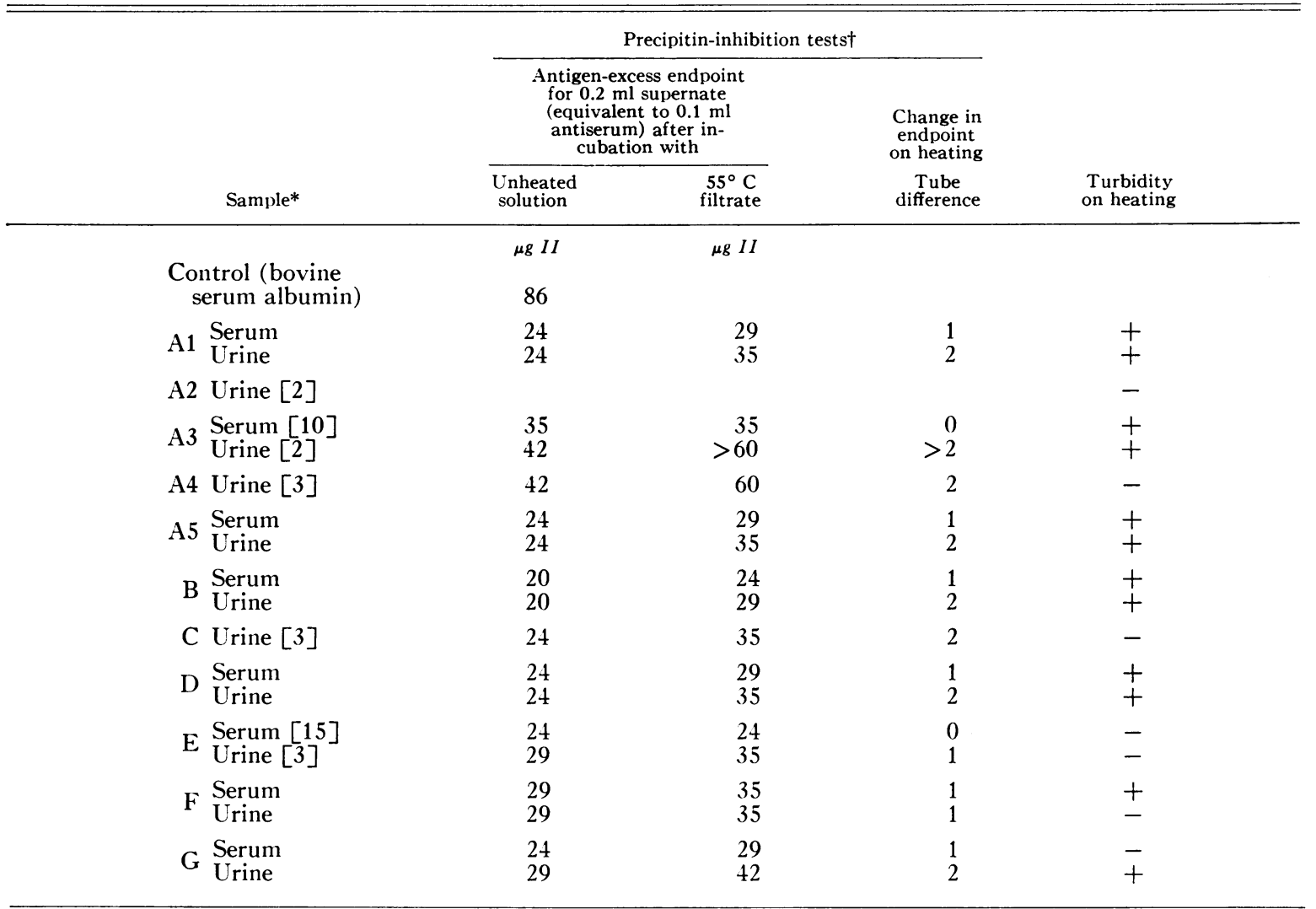

* "Serum" refers to serum globulins dissolved in $5 \mathrm{ml}$ of saline-acetate, "urine" to urine globulins dissolved in $1 \mathrm{ml}$. The solvent volume differed in some samples; for these, milliliters of solvent are indicated in brackets.

$\dagger$ Apart from Samples A3 and A4, the volumes of both unheated and heated solutions which were incubated with 1 $\mathrm{ml}$ of antiserum represented 0.1 total sample volume for urines, 0.02 total sample volume for sera. These were made up to $1 \mathrm{ml}$ with phosphate-buffered saline. The amounts of Fraction II used for titration were 20, 24, 29, 35, 42, 50, 60, 72 and $86 \mu \mathrm{g}$.

presence of gamma globulin. However, the utility of the procedure is reduced by decreased recoveries of Bence Jones proteins in $98^{\circ} \mathrm{C}$ filtrates when other heat-precipitable protein is also present.

The results of Experiment 3 suggest the presence among urine globulins of protein resembling Bence Jones protein in $a$ ) reacting with antibodies to gamma globulin; $b$ ) having a higher diffusion coefficient, as evidenced by curvature of Ouchterlony precipitin lines, than has $7 \mathrm{~S}$ gamma globulin; c) having a relatively high solubility at $98^{\circ} \mathrm{C}$, with the solute, on cooling, antigenically resembling the native protein. To these similarities can be added the results of studies at $55^{\circ} \mathrm{C}$, which are at least consistent with this protein's being readily denatured at this temperature. However, difficulties in detecting slight turbidity of urine solutions, and hence in correlating reduction in antigenic activity with this, and possible added complication due to the simultaneous presence of other proteins (23), indicate that interpretation of results from $55^{\circ} \mathrm{C}$ filtrates must be guarded.

Webb, Rose and Sehon (24) have reported physicochemical studies on electrophoretically separated urine gamma globulin, which suggest that this is virtually entirely represented by protein, antigenically related to serum gamma globulins, of molecular weight about 10,000 . It is difficult to see how such a population could have given the Ouchterlony plate appearances reported here. It may represent breakdown products of larger molecules, or it may have been missed in the present work due to the fact that it was not pre- 
cipitated by the ammonium sulfate (the concentration of which was chosen because it readily precipitates pathological Bence Jones proteins). These authors also give figures suggesting a daily gamma-related protein excretion of the order of $16 \mathrm{mg}$. This is much more than that suggested by the present study, in which protein reacting with the antiserum never exceeded $4.5 \mathrm{mg}$ per 24 hour urine.

The origin of the Bence Jones-like protein is undetermined. No overt breakdown of serum gamma globulin by dilution or by urine to give such a product has been demonstrated. If it enters the urine in its defined form it could come from plasma or from some source in the urinary tract. The gamma-related protein described by Webb and associates (24) appeared, from isotopic studies, to originate from the serum gamma globulins.

\section{SUMMARY}

In attempts to detect micro-amounts of Bence Jones protein, or of protein resembling it, advantage was taken of reports that all Bence Jones proteins react with antisera to gamma globulins. Experiments were planned so that protein detected by reaction with such an antiserum could be further characterized by heat stability at $55^{\circ} \mathrm{C}$, solubility at $98^{\circ} \mathrm{C}$, and diffusion coefficients.

Two preliminary experiments provided information on the behavior of serum gamma globulins and Bence Jones proteins at $55^{\circ}$ and $98^{\circ} \mathrm{C}$. Evidence was obtained from macroscopic behavior on heating and from immunochemical studies of heated products, that heat denaturation of Bence Jones proteins may be largely reversible.

Evidence was found of the presence, in normal urine, of protein which resembles Bence Jones protein in reacting with antibodies to gamma globulin, having a similar diffusion coefficient and having a relatively high solubility at $98^{\circ} \mathrm{C}$. Studies after heating at $55^{\circ} \mathrm{C}$, although inconclusive, were consistent with a further resemblance to Bence Jones protein in that the protein was readily denatured at this temperature.

\section{ACKNOWLEDGMENTS}

I am indebted to Professor C. R. B. Blackburn and Dr. G. M. Kellerman for advice, and to Mr. D. M. Fahey for technical assistance. Most of the Bence Jones protein samples were obtained through cooperation of the staff of the Royal Prince Alfred Hospital, Sydney.

\section{ADDENDUM}

Franklin (25) has provided further physicochemical studies of urinary protein of gamma electrophoretic mobility. He finds this to consist predominantly of a fraction which has a molecular weight of about 35,000 and is antigenically closely related to the serum gamma globulins; it was not thought to otherwise resemble Bence Jones protein. The suggested size of this protein is in accord with the present work, but some figures given by Franklin for its rate of excretion (his Table II) are much higher.

\section{REFERENCES}

1. Bence Jones, $\mathrm{H}$. On a new substance occurring in the urine of a patient with mollities ossium. Phil. Trans. 1848, 138, 55.

2. Jacobson, B. M., and Milner, L. R. Detection of urinary Bence Jones protein. Amer. J. clin. Path. $1944,14,138$.

3. Putnam, F. W. Aberrations of protein metabolism in multiple myeloma. Physiol. Rev. 1957, 37, 512.

4. Rundles, R. W., Cooper, G. R., and Willett, R. W. Multiple myeloma. IV. Abnormal serum components and Bence Jones protein. J. clin. Invest. 1951, 30, 1125.

5. Putnam, F. W., and Miyake, A. Proteins in multiple myeloma. VII. The free amino groups of BenceJones proteins. J. biol. Chem. 1957, 227, 1083.

6. Deutsch, H. F., Kratochvil, C. H., and Reif, A. E. Immunochemical relation of Bence-Jones proteins to normal serum proteins. J. biol. Chem. 1955, 216, 103.

7. Korngold, L., and Lipari, R. Multiple-myeloma proteins; III. Antigenic relationship of Bence Jones proteins to normal gamma-globulin and multiplemyeloma serum proteins. Cancer 1956, 9, 262.

8. Thije, O. J. T. Urinary and serum proteins in myelomatosis. Acta med. scand. 1956, 153, 253.

9. Snapper, I., Turner, L. B., and Moscovitz, H. L. Multiple Myeloma. New York, Grune and Stratton, 1953, p. 58.

10. McFarlane, A. S., Dovey, A., Slack, H. G. B., and Papastamatis, S. C. Unusual case of hyperglobulinaemia. J. Path. Bact. 1952, 64, 335.

11. Hughes, J. T. Carcinoma of bronchus with Bence Jones proteinuria. Brit. med. J. 1954, 2, 1267.

12. Collier, F. C., and Jackson, P. Precipitin test for Bence-Jones protein. New Engl. J. Med. 1953, 248, 409.

13. Burtin, P., Hartmann, L., Fauvert, R., and Graber, $P$. Etude critique des techniques d'identification de la protéine de Bence-Jones et de leur valeur diagnostique. Rev. franç. Et. clin. biol. 1956, 1, 17.

14. Oncley, J. L. Physical characteristics of the gamma 
globulins in Blood Cells and Plasma Proteins, James L. Tullis, Ed. New York, Academic Press Inc., 1953, p. 180.

15. Franklin, E. C., and Kunkel, H. G. Immunologic differences between $19 \mathrm{~S}$ and $7 \mathrm{~S}$ components of normal human gamma globulin. J. Immunol. 1957, 78, 11.

16. Grant, G. H. The proteins of normal urine. J. clin. Path. 1957, 10, 360.

17. Goa, J. Micro-biuret method for protein determination. Scand. J. clin. Lab. Invest. 1953, 5, 218.

18. Kabat, E. A., and Mayer, M. M. Experimental Immunochemistry. Springfield, Ill., Chas. C Thomas, 1948.

19. Grabar, P., and Williams, C. A. Méthode permettant l'étude conjuguée des propriétés électrophorétiques et immunochimiques d'un mélange de protéines. Biochim. biophys. Acta 1953, 10, 193.
20. Ouchterlony, Ö. Diffusion-in-gel methods for immunological analysis. Progr. Allergy 1958, 5, 1.

21. Fisher, R. A. Statistical Methods for Research Workers, 13th ed. Edinburgh, Oliver and Boyd, 1958.

22. Boyd, W. C. Fundamentals of Immunology, 3rd ed. New York, Interscience Publishers, 1956, p. 118.

23. Kleczkowski, A. The formation of protein complexes in heated solutions of rabbit serum proteins. Brit. J. exp. Path. 1941, 22, 188.

24. Webb, T., Rose, B., and Sehon, A. H. Biocolloids in normal human urine. II. Physicochemical and immunochemical characteristics. Canad. J. Biochem. 1958, 36, 1167.

25. Franklin, E. C. Physicochemical and immunologic studies of gamma globulins of normal human urine. J. clin. Invest. 1959, 38, 2159. 